\title{
RELATIONS BETWEEN WORKPLACE BULLYING, CONSCIENTIOUSNESS AND COUNTERPRODUCTIVE WORK BEHAVIOURS: A STUDY AT LOGISTICS COMPANY*
}

\author{
Meltem AKCA ${ }^{1}$, Mübeyyen TEPE KÜÇÜKOĞLU²
}

\begin{abstract}
Employee behaviors gets popular in today's academic and business environment because of its impact on organizational outcomes. Especially, increase of the dark attitudes of managers and colleagues towards the individuals, affects the formation of employees' deviance behaviors. In this context, workplace bullying is considered as one of the types of destructive approaches in organizations that excluding someone in social environment or influencing co-workers job sustainability with the harassment and offending emotions. Rising of workplace bullying in organizations leads employees to demonstrate negative behaviors which are defined as counterproductive work behaviors. On the other side, personality traits of an employee may have a major role in transformation of perception of negative attitudes towards to the work outcomes. For this reason, it was aimed to find out the role of conscientiousness, one of the personality traits of Five Factor Model, in the interaction between workplace bullying and counterproductive work behaviors. Statistical analyzes were made with the participation of 204 employees of a logistics company. According to findings it was revealed out that conscientiousness has a moderation role in the interaction between workplace bullying and counterproductive work behaviors.
\end{abstract}

Keywords: Workplace Bullying, Conscientiousness, Counterproductive Work Behaviors, Logistics

JEL Classification: M54, M12, C91

\section{IŞ YERI ZORBALIĞI, SORUMLULUK VE ÜRETKENLIKK KARŞITI IŞ̧ DAVRANIŞLARI ARASINDAKİ İLIŞKILER: LOJISTIK ŞİRKETINDE BİR ÇALIŞMA}

Öz

\begin{abstract}
Çalışan davranışları, örgütsel sonuçlar üzerindeki etkisi nedeniyle günümüzün akademik ve iş ortamında popüler hale gelmektedir. Özellikle yöneticilerin ve meslektaşların kişilere yönelik karanlık tutumlarının artması, çalışanların sapma davranışlarının oluşumunu etkilemektedir. Bu bağlamda, işyeri zorbalığı, organizasyonlarda bir çalışanı dışlayan veya iş arkadaşlarının iş sürdürülebilirliğini taciz ve rahatsız edici duygularla etkileyen yıkıcı yaklaşım türlerinden biri olarak kabul edilmektedir. Örgütlerde işyerinde zorbalığın artması, çalışanların üretkenlik karşıtı iş davranışları olarak tanımlanan olumsuz davranışlar sergilemelerine yol açmaktadır. Diğer taraftan, bir çalışanın kişilik özellikleri, olumsuz tutum algısının iş sonuçlarına dönüştürülmesinde önemli bir rol oynayabilir. Bu nedenle, beş faktör kişilik özelliklerinden sorumluluğun, işyerinde zorbalık ve üretkenlik karşıtı iş davranışları arasındaki etkileşimde rolünün belirlenmesi amaçlanmıştır. Lojistik şirketinin 204 çalışanının katılımıyla istatistiksel analizler yapılmıştır. Bulgulara göre, işyerinde zorbalık ve üretkenlik karşıtı iş davranışları arasındaki etkileşimde sorumluluğun düzenleyici rolü olduğu ortaya çıkmıştır.
\end{abstract}

\footnotetext{
* Çalışma, 2018 yılında gerçekleşen 4. Sosyal, Beşeri ve İdari Bilimler Sempozyumunda Türkçe olarak yer alan özet bildirinin farklı analiz yöntemleri ile tekrar test edilmiş ve genişletilmiş versiyonudur

${ }^{1}$ Dr. Öğretim Üyesi, Alanya Alaaddin Keykubat Üniversitesi, Gazipaşa Havacıllı ve Uzay Bilimleri Fakültesi, Havacılık Yönetimi Bölümü, meltem.akca@alanya.edu.tr, ORCID: 0000-0001-5544-5929

${ }^{2}$ Dr. Öğretim Üyesi, Trakya Üniversitesi, Keşan Yusuf Çapraz Uygulamalı Bilimler Yüksekokulu, Uluslararası Ticaret Bölümü, mtepekucukoglu@trakya.edu.tr, ORCID: 0000-0002-3717-4165
} 
Anahtar Kelimeler: İş Yeri Zorbalığı, Sorumluluk, Üretkenlik Karşıtı İş Davranışları, Lojistik

JEL Sinıflaması: M54, M12, C91

\section{Introduction}

It is well known that human capital has a significant impact on organization's sustainability and competitive advantage in today's market structure. Therefore, organizations need to benefit employees' productivity in correctly (Hitlan \& Noel, 2009:477). On the other side, negativity in the organizational environment generally impress employee's perceptions that can easily leads them to behave as counterproductive. Workplace bullying is considered as one of the antecedents of deviance behaviors of employees in organizations. According to Nielsen and colleagues (2010) \% 15 of working population around the world were exposed to negative behaviors that can be defined as bullying. Furthermore, $\% 11$ of the global working population also defines themselves as a victim of bullying (Einarsen \&Nielsen, 2015). Fox and Stallworth (2005) analyzed a participant group and revealed out that they experienced workplace bullying at least once in the last five years. Lutgen-Sandvik and colleagues (2007) also stated that \% 47 of the employees in United States of America were exposed to workplace bullying over the last two years. Finally, Boddy (2014) found that there is a positive and strong correlation between workplace bullying and counterproductive work behaviors.

In this context, there are various factors that can lead to negative or counterproductive work behaviors such as personal factors and organizational factors (Instone, 2012). Leadership, working conditions, organizational support, job content, work environment, bullying can be classified under organizational factors that form the counterproductive work behaviors. Moreover, it is believed that personality traits also have a significant impact on workplace bullying etiology (Einarsen et al, 2011). Personality traits both influence the individual perception of the external events and direct the emotions to cope with negative situations (Semmer, 2003).

Many researchers in organizational behavior and human resource management area tried to explain the roles of the employee relations and work environment on work performance and individual behaviors (Devonish, 2013). In literature there exist limited studies searching the relationship between workplace bullying, conscientiousness, and their impact on counterproductive work behaviors in the organizations. For that reason, in this study it was aimed to find out the moderation role of conscientiousness, which is a positive personality trait, in the interaction between workplace bullying and counterproductive work behaviors. Accordance with this aim, theoretical framework was mentioned, and methodology was designed. Findings of the statistical analyzes demonstrated that conscientiousness has a moderation role in the interaction between workplace bullying and counterproductive work behaviors. 


\section{Theoretical Framework}

\subsection{Workplace Bullying}

Workplace bullying is an organizational trouble in today's business environment. Consequences of workplace bullying on employees and organization also bring this concept to the light. Moreover, enhancement of corporation complaints about bullying also plays a major role for analyzing workplace negative behaviors like mobbing and bullying. In this context, excluding someone in social environment or influencing co-workers job sustainability with the harassment and offending emotions is considered as workplace bullying (Einarsen et al., 2011:22). Furthermore, persistency, frequency, intensity of negative behaviors and perception of power imbalance (not required hierarchical) between sides are assumptions of the bullying concept (Fox \& Stallworth, 2005; Bulutlar \& Unler Oz, 2009; Lutgen-Sandvik, Tracy \& Alberts, 2007). It is also important to emphasize that bullying should be regularly or repeatedly (weekly) over a period (about six months) to conceptualize it as a workplace bullying. In this context, over intimidation, verbal and non-verbal negative behaviors, violence, belittling, humbling, irritating, hurdling, angry behaviors, stressful change in employee's tasks, work and time pressure, dangerous working conditions, social isolation and direct attacks are some of bullying related actions (Einarsen \& Nielsen, 2015; Samnani \& Singh, 2014; Einarsen et al., 2011; Parzefall \& Salin, 2010; Fox \& Stallworth, 2005). In the literature, workplace bullying, and mobbing is generally used to point out the undesired phenomenon in the organizations. In fact, in many studies to reveal out the workplace bullying, it is seen that these two concepts are announced together (Einarsen, 2003; Matthiesen \& Einarsen, 2004; Salin, 2011). Furthermore, workplace harassment (Björkqvist, Österman \& Hjelt-Back, 1994), emotional abuse at work (Keashly, 1998), workplace aggression (Baron \& Neuman, 1996), workplace incivility (Cortina et al., 2001) are some of the notions which are used in researches within the meaning of workplace bullying.

Salin (2015) classified workplace bullying phenomena under two dimensions as work related (organizational) and interpersonal. Unjustified criticism, sabotage, withholding relevant information are generally considered as work-related bullying. On the other side, gossip, rumors, aggressive and hateful comments for co-worker's attitudes and political-religiousracial related discrimination are evaluated as interpersonal bullying. Furthermore, according to the Francioli and colleagues (2016) literature distinguished workplace bullying under two main approaches. As the first one "work environment" perspective by Leymann (1996), it was stated that workplace bullying is a result of negative working conditions which includes physical and psychosocial elements (Salin \&Hoel, 2011). In this context, a poor work environment increases the risk of bullying behaviors in organizations. Besides, aggressive, and laissez-faire leadership style, unfair competition and performance systems, poor physical working conditions and discrimination may influence workplace bullying formation (Salin, 2015). Leymann (1996) also divides workplace bullying into five stages. In the first stage disagreement and similar critical events trigger the existence of conflicts. Later, an active state of bullying through attacks on intimidation under the name of psychological harassment starts to be observed. In the third stage, if the person who has been bullied cannot be understood by the management, the solution becomes more difficult with the misunderstanding and then the victim starts to be labeled with various adjectives. 
In the last stage, the victim quits his/her job and ends his/her career and struggles with various psychological disorders along with emotional tension.

Farr-Wharton and colleagues (2017) established a mutual relation with workplace bullying phenomena and Social Exchange and Leader-Member Exchange Theories. Social Exchange Theory supports that when organizational structure and environment satisfy the needs of employee's well-being and task requirements, interaction between all members may be effective and beneficial. Concordantly, providing organizational trust with sharing information and powering relations also have a major role over the organizational sustainability (Cropanzano \& Mitchell,2005). If there is not a social environment that employees can share and change their knowledge and experience, then bullying comes into being by itself. On the other side, it is generally accepted that bullies are at senior level leaders and managers. However, it is not required a hierarchical bully-victim interaction, it was seen from the literature and cases that a huge majority of the workplace bullying is actualized between superior-and subordinate. To the extent that, Leader-Member Exchange Theory explains the quality of the relationship between leaders and employees (Hooper \& Martin, 2008). In the meantime, Leader-Member Exchange Theory lays emphasis on that a good relation between superior and employees plays an adverse impact over bullying occurrence (Farr-Wharton et al, 2017).

On the other side, in the perspective of Cognitive Trauma Theory, Carnelley and JanoffBulman (1992) states that victims of bullying react with fear, anxiety, stress, depression, and pain. Furthermore, depending on these traumatic results, perceptions of victims about the future may also shaped with threat, danger, and self-questioning (Mikkelsen \& Einarsen, 2002). Besides, mental problems, burn out, health problems, sleep disturbance and related symptoms appear to happen with workplace bullying behaviors (Francioli et al., 2016; Einarsen \& Nielsen,2015). Finally, it is also possible to say that bullying increases the degree of job insecurity in the workplace over time that leads loss of satisfaction, commitment, performance and well-being; increased turn over, absenteeism and intention to leave (Glambek, Skogstad \& Einarsen, 2018; Salin, 2015; Einarsen \& Nielsen, 2015; Berthelsen et al, 2011; Rodriguez-Munoz et al., 2009).

\subsection{Conscientiousness}

In the past decades, scholars' analyzed human's characteristic features that leads personality traits occurrence. However, it is still not a consensus over a personality traits, similar humanity features were established as personality traits in the literature (Akgündüz \& Akdağ, 2014:299) Even though there have been different theories about personality traits, Five Factor Model is generally one of the most preferred one by researchers. According to Costa and McCrae (1992) five factors for personality traits which are internationally accepted as similar. Mc Crae and John (1992) described that five factors about personality are biological in origin and have the validity around the world (Pervin, 1993). These factors are listed as, extraversion, agreeableness, conscientiousness, neuroticism, and openness to experience (Costa \& McCrae 1992).

Personality traits are generally being thought as a predictor of employees' behaviors (Witt et al, 2002; Somer, 1998:30).

For this reason, personality traits have been studied in the behavioral related studies. 
In this research, it was aimed to analyze the role of conscientiousness in the interaction between workplace bullying and counterproductive work behaviors. Therefore, it was only conscientiousness mentioned here.

Conscientiousness is one of the personality traits of Five Factor Model (Costa \& McCrae 1992). Mc Crae and John (1992) defined conscientiousness as a hardworking, organized, rule based and self-disciplined. Besides, planned behaviors of conscientiousness and selfresponsible employees organize the job requirements more detailed (Heyde et al., 2014:3). In addition to these, conscientiousness is considered as a task-oriented personality trait (Bowling et al., 2011). Conscientiousness is also accepted as more adaptive to achieve work aims and individual job outcomes than other personality traits (Judge \& Ilies, 2002). Moreover, conscientious people target to i) reach success and ii) scrabble complete tasks effectively. They generally follow the rules of the organization. Finally, conscientiousness increases the job productivity and competition in the organization that triggers rise of sustainable performance (Kim \& Glomb 2014; Jensen, Patel \&Raver, 2014).

\subsection{Counterproductive work behavior}

Employees' dark behaviors get popular day by day in the management and the occupational psychology studies due to their negative impact on organizational and individual job outcomes. In this context, counterproductive work behavior is one of the most used concepts for deviant and dark behaviors in the workplace (Heyde et al., 2014:1). Counterproductive work behavior (CWB) is considered as conscious behavior which has the risk of devastation on organization and its members (Spector \& Fox, 2005). Spector and Fox (2005) defined CWB as an employee behavior that has the intention and act to damage the organization, employees, customers, supervisors, co-workers, leaders, clients, and shareholders. CWB is also accepted as dangerous behaviors of employees that can harm the organizational functions and processes (Fox, Spector \& Miles, 2001:292). Besides, Penney, Hunter and Perry (2011) stated that wasting time, rudeness, withholding effort and sabotage are comprised of CWB. Furthermore, drug use, alcohol use, inappropriate physical actions, unsafe behaviors, poor attendance, inappropriate verbal actions, destruction of property, misuse of time and resources, theft and related behaviors, workplace aggression, anger, frustration, ignoring others, employee deviance and imprudent behaviors are listed under counterproductive behavior (Heyde et al., 2014:2; Penney,Hunter \& Perry, 2011:60; Gruys \& Sackett, 2003:38).

Collins and Griffin (1998) defined counterproductive work behaviors as dark behaviors which may change in a range low to high. According to researchers, while petty stealing looks like a low-level counterproductive behavior, on the other hand violence is observed as a high-level counterproductive behavior. Hogan and Hogan (1989) also noted that all deviant behaviors from absenteeism to assault should be examined as counterproductive work behaviors. In addition to these, Spector and colleagues (2006) explained CWB in five examples as abuse, passive behaviors, sabotage, theft and withdrawal. In this perspective, abuse against others is described as physical and psychosocial dangerous actions. Passive behaviors to decrease production is also explained as production deviance. Sabotage is taken as a physical damage on the organizational properties. Theft is stealing things from company including organizational information. Finally, withdrawal is related behaviors with reducing work hours. 
Generally, CWB is comprised of organizational and interpersonal related dark behaviors. While CWB-O (Organization) intents to harm organization directly, CWB-I (Interpersonal) focuses on other employees (Spector et al., 2006; Robinson \&Bennett, 1995). Reference to this approach; sabotage, withdrawal, production deviant is evaluated as CWB-O, whereas abuse, interpersonal conflicts, gossip, revenge, aggressive reaction, anti-social behaviors, impoliteness physical injuries are considered as CWB-I (Abdullah \& Halim, 2016:3; Abas et al., 2015:100). However, accidental actions which may damage to organizational process or members should not have announced as counterproductive work behaviors. It should be noted that counterproductive work behaviors are harmful behaviors which are planned and intended to act (Gruys and Sackett, 2003:30).

Spector and Jex (1998) and Jex and Beehr (1991) also indicated that CWB is a response to perceived workplace related stressors. According to the Social Learning Theory (Decker, 1986), human behaviors are shaped with the observed behaviors of others. Specifically, leader or manager behaviors play a major role for employees in organizations. If leader's behaviors are perceived as negative or toxic, employee behaviors are also started to assimilate like unfavorable in organizations. In the circumstances, harmful behavioral intentions come to exist which is called as counterproductive work behaviors (Boddy, 2014:108; Hauge, Skogstad \& Einarsen, 2009). Nevertheless, Social Exchange Theory, Cognitive Social Theory, General Strain Theory are also considered as some explanatory theories that can help to explain why employee's behaviors transform to the counterproductive in organizations (Abdullah \&Halim, 2015 :3).

Counterproductive work behaviors (CWBs) of employees induce huge financial losses per year (Bennett \& Robinson, 2000). For example, employee's theft and dark behaviors cost approximately billion dollars annually in USA (Greenberg, 1997). In addition to financial performance defaults, counterproductive work behaviors also damage the organizational image in the business environment (Kozako, Safin \& Rahim 2013:182). CWBs decrease productivity, profitability, efficiency, and performance in organizations (Deshong, Gront \& Mullins-Sweatt, 2015:55; Nasir \& Bashir, 2012). Furthermore, CWBs decline the job performance, job satisfaction and individual success of employees in the workplace (Herschcovis \& Barling, 2010). Since having large potential effects to an organization, precautions need to be taken to diminish the risk of negative outcomes of CWB in the workplace (Instone, 2012). There are many ways in organizations to avoid the damages of CWBs. Some of these are; supporting communication, creating an atmosphere of mutual trust to express their feelings and thoughts, taking into account the thoughts of the employees in the organization and making them to participate into various decision and change processes, preventing organizational silence resulting from the lack of knowledge and skills (Gültaç \& Erigüç, 2019).

\section{Hypotheses Development and Methodological Framework}

Individual's perception of the environment and attributions for the events, emotional responses and abilities are generally related with personality traits (Kozako, Safin \&Rahim, 2013:182). Pervin (1993) and Leymann (1996) underlined the importance of character and personality on the human's feelings, emotions, attitudes, and behaviors. 
Colbert and colleagues (2004) also emphasized the differences of personality traits of employees that influence the perception of the work environment. According to Ajzen and Fishbein's Attitude Behavior Theory (1977), personality and CWB relates to each other. Moreover, differences in personality make variation on counterproductive work behaviors (Kozako,Safin \&Rahim,2013:182; Bowling et al., 2011; Spector, 2005; Elliot, 2010; KishGephart, Harrison \&Trevino, 2010; Hastings \& O’Neill, 2009). Otherwise, negativity of employees' perception about workplace events also triggers CWBs in the organizations (Martinko, Gundlach \& Douglas, 2002).

Bowling and colleagues (2011) investigated the literature about counterproductive work behaviors and obtained that predictors of these behaviors distinguished as situational predictors (work stressor, leadership styles) and personality traits (neurotics, conscientiousness). Kozako, Safin and Rahim (2013) researched the articles which were related to conscientiousness and counterproductive work behaviors. According to the results, in generally, negative relations were obtained between variables (Kozako, Safin \&Rahim, 2013). Berry, Ones and Scott (2007) analyzed the relationship between counterproductive work behaviors and personality traits. As far as the study's results, it was revealed out that while agreeableness is related with interpersonal CWB-I, conscientiousness relates to CWBO. A further study's results also indicated that agreeableness and conscientiousness are negatively related with counterproductive work behaviors (Deshong, Gront \& Mullins-Sweatt, 2015:55).

On the other side, Persson and colleagues (2016) stated that focusing on individual differences may be helpful for understanding bullying problem. Nielsen, Matthiesen and Einarsen (2008) also explained that personality traits of a victim play an important role for bullying actions. For example, neuroticism, low emotional stability, and low conscientiousness are positively related with bullying (Glaso et al., 2007). Generally, victims of bullying work harder to intervene aggressive pressure of bully. Conscientiousness is observed in the victims of bullying to avoid themselves against the perpetrator's power (Hoel et al., 2011). Furthermore, Nielsen and Knardahl (2015) found that victimization of workplace bullying is related with lower levels of conscientiousness. In addition to these explanations, reference to some empirical studies it was also obtained that there is a negative relationship between bullying and conscientiousness (Glaso et al., 2007; Hitlan, Cliffton \& Desoto, 2006; Bamberger \& Bacharach, 2006). In another perspective, conscientiousness increases the job productivity and competition in the organization that may cause an intolerance to other employees. In this way, sometimes conscientious people may exposure to the bullying by other employees (Kim \& Glomb, 2014; Jensen, Patel \&Raver, 2014). Otherwise, if responsible employees' expectations (reward, bonus, promotion) are not met or if they are not appreciated for their efforts, they may also perceive a bullying on them (Nielsen \& Knardahl, 2015:132).

Reference to upper explanations, in this study, it was aimed to find out the moderator role of conscientiousness on the interaction between workplace bullying and counterproductive workplace behaviors. Research model and hypothesis were formulated in accordance with the literature. In this section, research methodology was mentioned, and statistical analyses were explained. Finally, results were discussed in relation with the theoretical perspective. 


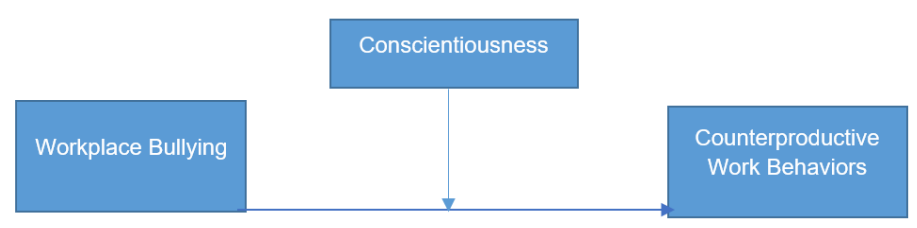

Figure 1: Research Model

Accordance with the model, hypothesis of the study was formed as.

$\mathrm{H}_{1}$ : Workplace bullying has a positive impact on employees' counterproductive work behaviors.

$\mathrm{H}_{2}$ : Conscientiousness moderates the impact of workplace bullying on employees' counterproductive work behaviors such as conscientiousness reduce the positive effect of workplace bullying on employees' counterproductive behaviors.

In this study it was used of Einarsen, Hoel and Notelaers's (2009) "Negative Acts Questionnaire-Revised Form, work-related bullying sub-dimension to measure workplace bullying with 6 items. Conscientiousness was also measured with the related sub-dimension of Costa and McCrae's (1992) Five Factor Model Questionnaire. The dimension has 6 items. Furthermore, it was benefit from Spector and colleagues' (2006) Counterproductive Work Behaviors Scale's abuse related sub-dimension. In the questionnaire form, sample items were rated 5 points Likert Scale ranging between 1 (completely disagree) and 5 (completely agree) in all scales. There were also four demographic questions in the last part of the questionnaire form which were not needed to respond mandatory.

The sample of this study consists of a logistics company's employees in Istanbul. Logistics industry has been progressed for last two decades rapidly. Development of technology usage, enhancement of e-business operations trigger the scope of logistics related organizations. Because of logistics is a service industry, employees' work outcomes have a major role on operational success and customers' satisfaction. In this context, the population of this study was generated from the sampling formulation. There were 408 employees in the company. Considering error margin and confidence interval, it was found suitable 198 forms were enough for statistical analyses (Barlett et al., 2001). 300 questionnaires were dispensed to the employees with the convenience sampling method. At the end of the 10 days it was acquired 204 valid and errorless questionnaire forms.

In this study to provide regression analysis assumptions, the normality and correlation analysis tests and factorial structures of the scales were investigated by IBM SPSS Statistics 21.00 Program. In the normality tests, diagrams, and Skewness-Kurtosis values; it was accepted that the data demonstrated normal distribution. To test relationships between workplace bullying and conscientiousness, conscientiousness and counterproductive work behaviors and workplace bullying and counterproductive work behaviors, correlation analysis were used. 
Finally, with the regression model, the research hypothesis supported in the IBM SPSS Statistics 21.00 Process Macro Program Tests (Hayes, 2018).

\subsection{Findings}

According to results of statistical analyses made by SPSS 21.00 Program, factorial structures of the scales tested by Explanatory Factor Analysis with the usage of Varimax Rotation. Findings showed that scales have acceptable construct validities. KMO values of the scales are 0.805 for workplace bullying, 0.854 for conscientiousness and 0.778 for counterproductive work behavior. Besides, scales have high explanations. Factor loadings also observed between 0.962-0.981 for workplace bullying, 0.955-0.968 for conscientiousness and 0.935-0.960 for counterproductive work behavior.

Table 1: Explanatory Factor Analysis Results

\begin{tabular}{|c|c|c|c|}
\hline Indicator & $\begin{array}{c}\text { Workplace } \\
\text { Bullying }\end{array}$ & Conscientiousness & $\begin{array}{c}\text { Counterproductive } \\
\text { Work Behavior }\end{array}$ \\
\hline KMO: & 0.805 & 0.854 & 0.778 \\
\hline Chi Square: & 2954.147 & 1155.166 & 1247.194 \\
\hline Df: & 15 & 6 & 6 \\
\hline Sig: &, 000 &, 000 & $\% 00$ \\
\hline Explanation: & $\% 94.485$ & $\% 92.588$ & $0.935-0.960$ \\
\hline $\begin{array}{c}\text { Range of Factor } \\
\text { Values: }\end{array}$ & $0.962-0.981$ & $0.955-0.968$ & \\
\hline
\end{tabular}

In this study, it was benefit from Cronbach's Alpha value to analyze the reliabilities of measures. Reference to the findings, it was revealed out that all scales have good Cronbach's alpha values as; workplace bullying $(\alpha=0.988)$, conscientiousness $(\alpha=0.967)$ and counterproductive work behaviors $(\alpha=0.931)$. Besides, means of variables were obtained as: workplace bullying 4.28, conscientiousness 3.30 and counterproductive work behaviors 3.67. It was also used Pearson Correlation Tests to discuss the relationships between variables. Findings demonstrated that there is a positive and statistically significant relationship between workplace bullying and conscientiousness $(\mathrm{r}=0.276)$ while a negative relationship between conscientiousness and counterproductive work behavior $(r=-0.458)$. Furthermore, it was found that there is a positive relationship between workplace bullying and counterproductive work behaviors $(\mathrm{r}=0.565)$.

Table 2: Means, Standard Deviations, Reliability Coefficients and Pearson Correlation Analysis Results

\begin{tabular}{|r|c|c|c|}
\hline \multicolumn{1}{|c|}{ Scales } & $\begin{array}{c}\text { Workplace } \\
\text { Bullying1 }\end{array}$ & Conscientiousness2 & $\begin{array}{c}\text { Counterproductive } \\
\text { Work Behaviors3 }\end{array}$ \\
\hline Indicators & 4.28 & 3.30 & 3.67 \\
\hline$\overline{\mathrm{x}}$ & 1.25 & 0.92 & 1.14 \\
\hline s.d & 0.988 & 0.967 & 0.931 \\
\hline$\alpha$ & - & $0.276^{* *}$ & $0,565^{* *}$ \\
\hline 1 & $0,276^{* *}$ & - & $-0.458^{* *}$ \\
\hline 2 & $0.565^{* *}$ & $-0.458^{* *}$ & - \\
\hline 3 & & & \\
\hline
\end{tabular}


For Analyzing Moderation Impact, it was used SPSS Program Process Macro. Moreover, in this study it was used Regression Analysis with the usage of Bootstrap Method (Hayes, 2018; Gürbüz, 2019). Reference to the results, it was revealed out that moderation role of conscientiousness is statistically significant. Findings showed that $\% 33.58$ of variation on the counterproductive workplace can be explained by workplace bullying $(\mathrm{X})$, conscientiousness (M) and moderator (X.M). Besides, in Table 3, it is seen that Beta coefficient of moderation variable (X.M) is statistically significant $(b=-0.7652$, \%95 CI $[-1.7722,-1.1608], t=-$ 9.4446, $\mathrm{p}<0.05)$. Findings demonstrate that moderation is statistically significant due to the $\mathrm{p}<0.005$. CI values also do not include 0 value (Gürbüz, 2019).

Table 3: Modal Summary and Coefficients Table of Regression Analysis (Process Macro)

\begin{tabular}{|c|c|c|c|c|c|c|}
\hline Model & coeff & se & t & p & LLCI & ULCI \\
\hline Constant & 2.9128 & .0664 & 19.8761 & .000 & 2.7821 & 3.0435 \\
\hline $\begin{array}{c}\text { Workplace } \\
\text { Bullying(X) }\end{array}$ & .598 & .0972 & 7.6116 & .000 & .5487 & .9316 \\
\hline Conscientiousness(M) & .326 & .0565 & 3.0966 & .0022 & .0637 & .2861 \\
\hline X.M & -.7652 & .1553 & -9.4446 & .000 & -1.7722 & -1.1608 \\
\hline
\end{tabular}

Additionally, it was obtained conditional effects of the focal predictor at values of the moderator (s) as -1.30 (low), 0.44 (medium) and 1.44 (high) levels. In this context, when conscientiousness is low $(-1.30)$, the positive interaction between workplace deviance and counterproductive work behaviors is statistically significant $(b=.647, \% 95$ CI [ 2.0892, 3.2056], $\mathrm{t}=-9.3382, \mathrm{p}<0.05)$. When conscientiousness is at medium level $(0.44)$, positive interaction between workplace bullying and counterproductive work behaviors is not statistically significant $(b=0.811, \% 95$ CI [ $-0.420,20.42], t=1.2966, p=0.1959)$. On the other side when there is a high conscientiousness, (1.44) positive interaction between workplace bullying and counterproductive work behaviors turns to negative $(b=-.591, \% 95$ CI $[-1.7060$, $-1.0648], \mathrm{t}=-8.5076, \mathrm{p}<0.05)$.

Table 4: Moderation Impact at Different Values

\begin{tabular}{|l|l|l|l|l|l|l|}
\hline Moderator & Effect & se & t & $\mathbf{p}$ & LLCI & ULCI \\
\hline-1.30 & .647 & .2835 & 9.3382 & .000 & 2.0892 & 3.2056 \\
\hline 0.44 & 0.811 & .0625 & 1.2966 & .1959 & -0.420 & 20.42 \\
\hline 1.44 & -.591 & .1628 & -8.5076 & .000 & -1.7060 & -1.0648 \\
\hline
\end{tabular}

*Level of confidence for all intervals is 0.95 .

In addition to upper explanations, as it is observed from the Figure 2 below, positive interaction of workplace bullying on counterproductive work behaviors turns to negative when conscientiousness increases. 


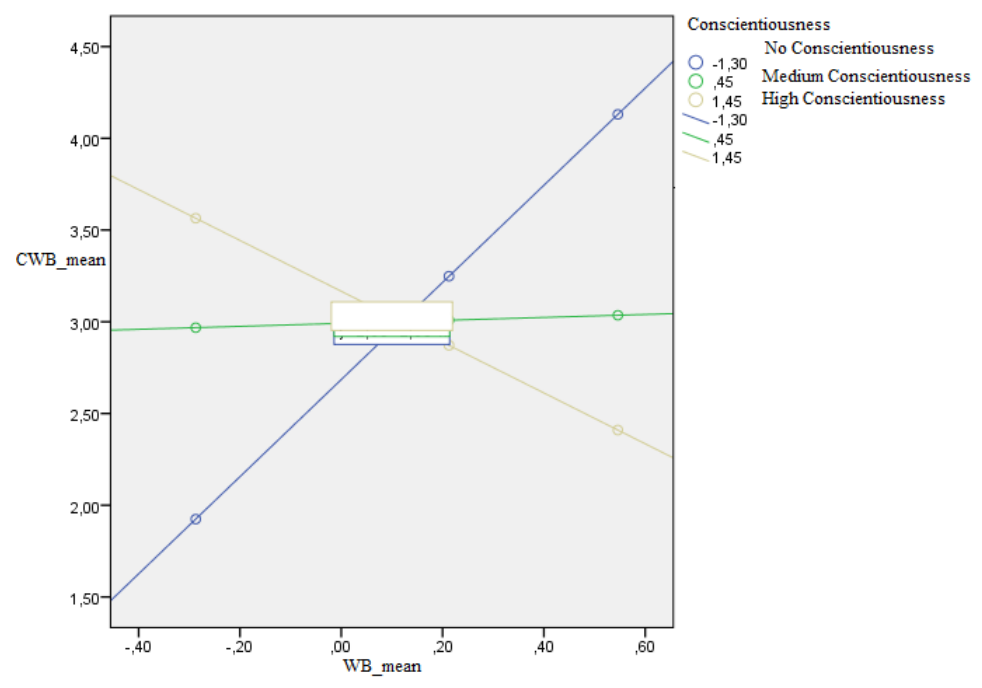

Figure 2: Moderation Chart

\section{Conclusion}

The workplace bullying mentioned by Leymann (1996) for the first time in business life by citing the concept as a situation of individual or organizational origin. In this context, workplace bullying was defined as behaviors that comprised of harmful emotions in organizations (Leymann, 1996). Özkalp and Kırel (2016) argued that situations such as hostility, jealousy, competition, and lack of understanding trigger workplace bullying behavior. Besides, personality, organizational structure, insufficiency of managers, cultural structure and legal gaps are determined as antecedents of workplace bullying (Öksüzoğlu \& Şeşen, 2018). Ayoko, Callan and Härtel (2003) also emphasized that most common bullying behaviors are evaluated as; being ignored, withholding information, unrealistic targets, belittling remarks, intimidation, criticism, or verbal threats.

Reference to upper explanations, workplace bullying is considered as a serious organizational problem that can have many negative consequences for both employees and the organization. Researches showed that problems such as sleep disorders (Lallukka, Rahkonen \& Lahelma, 2011), high levels of anxiety (Rodríguez-Muñoz, Moreno-Jiménez \& Sanz-Vergel, 2015), difficulty in concentration (Einarsen \& Mikkelsen, 2003), lower self-esteem and selfefficiency (Chang, Su, \& Mizanur, 2018; Hsieh, Wang, \& Ma, 2019), burn out (Livne \& Goussinsky, 2018; Purpora et al., 2019), post-trauma stress disorder (Matthiesen \& Einarsen, 2004), depression (Chang, Su, \& Mizanur, 2018; Miller et al., 2019), psychosomatic health problems (Björkqvist et al., 1994), physical problems (Ciby \& Raya, 2018; Glambek et al., 2018; Lever et al., 2019) are observed as consequences of workplace bullying related employees' reactions. Furthermore, O'Moore and colleagues (1998) pointed out that workplace bullying not only influences physical and mental health of employees but also damages the careers of victims.

In this context, it is well known that employees' problems can also directly affect organizational productivity. 
In addition, being a target of bullying negatively affects job satisfaction and job performance (Einarsen \& Raknes, 1997; Einarsen, Matthiesen \& Skogstad, 1998; Quine, 2001).

Employee performance is an important issue for maintaining organizational efficiency and effectiveness, and workplace bullying becomes an obvious threat for companies whose main goal is to ensure that the performance at the highest level to maximize profit and secure competitive advantage (Devonish, 2013). Besides, workplace bullying increases cynicism (Kaya, Tekpınar \& Tekin, 2019), organizational silence (Harlos \& Knoll, 2018; Demirtas, 2018), anti-productive business behaviors (Einarsen et al., 2011) and intention to leave (Hsieh, Wang, \& Ma, 2019), while causes reduced work engagement (Einarsen et al., 2018) and less organizational citizenship (Constantino, Domingez \& Galan, 2006).

On the other side, counterproductive work behaviors can be thought as a shape of protest within the organization by members to express their dissatisfaction or act to resolve injustice (Kelloway et al., 2010). For example, wasting company material and supplies, doing someone's work incorrectly and damaging a valuable piece of property belonging to the employer on purpose are defined as counterproductive work behaviors (Ayoko, Callan \& Härtel, 2003).

Workplace bullying is considered as a kind of social stressor that affects the psychosocial work environment in ways by forming organization as damaging and destructive for employees and itself (Hauge, Skogstad \& Einarsen, 2010). Regarding counterproductive work behaviors, Bruk-Lee and Spector (2006) pointed out the significant role of social stressors (e.g. interpersonal conflict) on counterproductive work behaviors and informed that employees who experience negative emotions or displeasure will respond with counterproductive work behaviors against people causing these negative feelings. Boddy (2014) also stated that corporate psychopaths have large and significant impacts on bullying and these people also play a major role on existence of counterproductive work behavior. In this perspective, Boddy (2014) i) found that there is significant correlation between conflict (including bullying) and counterproductive work behaviors and ii) noticed that higher levels of workplace bullying were obtained as predictive of workplace counterproductive behaviors.

Besides, in organizational behavior literature there are some studies that have discussed the effect of personality trait of Five Factor Model on CWBs. One of the personality traits is conscientiousness which relates to impulse control and contains behaviors such as thinking before doing something (Chang \& Smithikrai, 2010). Reference to the related studies, conscientiousness is evaluated as a predicting composite measure of CWBs (Koç \& Bayraktar, 2019; Farhadi et al., 2012; Instone, 2012; Bolton, Becker \&Barber, 2010). Moreover, in another study, all five of the personality traits found to influence CWBs, whereas strongest predictor was obtained as conscientiousness (Chang \& Smithikrai, 2010). Nevertheless, Hafidz (2012) determined that conscientiousness (out of the five-personality factor) was revealed out to be negatively correlated with CWBs.

Accordance with the upper explanations, in this study it was aimed to find out the moderation role of conscientiousness on the interaction between workplace bullying and counterproductive work behaviors. For this purpose, conceptual framework and hypothesis development were designed in detail. Furthermore, research model and hypothesis were also figured. 
According to results of statistical analyses made by SPSS 21.00 Program, means of variables were obtained as: workplace bullying 4.28, conscientiousness 3.30 and counterproductive work behaviors 3.67. It was also used Pearson Correlation coefficients to discuss the relationships between variables. Additionally, it was revealed out that all scales have good Cronbach's alpha values as; workplace bullying $(\alpha=0.988)$, conscientiousness $(\alpha=0.967)$ and counterproductive work behaviors $(\alpha=0.931)$. Moreover, factorial structures of the scales tested by Explanatory Factor Analysis with the usage of Varimax Rotation. Findings showed that scales have acceptable construct validities. Finally, it was obtained conditional effects of the focal predictor at values of the moderator as -1.30 (low), 0.44 (medium) and 1.44 (high) levels. In this context, when conscientiousness is low (-1.30), the positive interaction between workplace deviance and counterproductive work behaviors is statistically significant ( $b=.647$, \%95 CI [ 2.0892, 3.2056], $\mathrm{t}=-9.3382, \mathrm{p}<0.05)$. When conscientiousness is at medium level (0.44), positive interaction between workplace bullying and counterproductive work behaviors is not statistically significant $(\mathrm{b}=0.811, \% 95$ CI [ $-0.420,20.42], \mathrm{t}=1.2966, \mathrm{p}=0.1959)$. On the other side, when there is a high conscientiousness (1.44) positive interaction between workplace bullying and workplace deviance turns to negative $(b=-.591, \% 95$ CI $[-1.7060$, 1.0648], $\mathrm{t}=-8.5076, \mathrm{p}<0.05$ ). Findings demonstrated that when the moderation variable takes different values (low-medium-high), interaction of workplace bullying on counterproductive work behaviors tends to change. For example, when conscientiousness has a low level, the positive impact of workplace bullying on counterproductive work behaviors increase, whereas if conscientiousness is high, this positive impact turns to negative. This means that, increase of conscientiousness transform the positive impact of workplace bullying on CWB to negative. While employees who have low level of conscientiousness show counterproductive work behaviors due to the workplace bullying, employees with high conscientiousness do not demonstrate counterproductive work behaviors as the employees who have low level, although they experience workplace bullying. This result supports $\mathrm{H}_{2}$ that emphasizes the moderation impact will reduce the positive affect of workplace bullying on counterproductive behaviors. Moreover, it is important to underline that moderation not only reduce the positive impact between variables, but also transform the positive impact to negative.

Conscientious employees are likely to be more productive and engage in fewer CWBs than less conscientious employees due to having more control over their work-related behaviors (Ones \& Viswesvaran, 1996). For that reason, personality traits related tests during employment have positive impacts on work outcomes more than normal expectations. Moreover, Ciby and Raya (2014) emphasized that the victims should be empowered with some awareness programs and organizational support to diminish the outcomes of workplace bullying.

In this study, it was used one logistics company's employees to analyze relationships between variables in micro level. For that reason, findings are not generalized for all companies. In further studies, the scope of the companies is required to increase. Besides, enhancement of the model with other personality traits, it will provide better results. In this study, demographic variables related questions were not mandatory. So, differences between participant groups among research variables were not studied detailed. Next studies may also focus on age, education, occupation etc. related variables. 


\section{References}

Abas, C., Omar, F., Halim, F. W., \& Hafidz, S. W. M. (2015). The mediating role of organizational-based self-esteem in perceived organizational support and counterproductive work behaviour relationship. International Journal of Business and Management, 10(9), 99-108.

Abdullah, A., \& Halim, F. W. (2016). The influence of work ethic and counterproductive work behaviour of civil servants. Journal of Technology Management and Business, 3(1), 1-14.

Ajzen, I., \& Fishbein, M. (1977). Attitude-behavior relations: A theoretical analysis and review of empirical research. Psychological bulletin, 84(5), 888-918.

Akgündüz, Y., and Akdağ, G. (2014). İşgörenlerin kişilik özelliklerinin temel benlik değerlendirmelerine ve işten ayrılma niyetlerine etkisi. Yönetim Bilimleri Dergisi, 12(24), 295-318.

Ayoko, O., Callan, V. and Härtel, C. (2003), Workplace Conflict, Bullying, and Counterproductive Behaviors. The International Journal of Organizational Analysis, 11(4), 283-301.

Bamberger, P. A., \& Bacharach, S. B. (2006). Abusive supervision and subordinate problem drinking: Taking resistance, stress and subordinate personality into account. Human Relations, 59, 723-752.

Barlett, J. E., Kotrlik, J. W., \& Higgins, C. C. (2001). Organizational research: Determining appropriate sample size in survey research. Information technology, learning, and performance journal, 19(1), 43-50.

Bennett, R. J., \& Robinson, S. L. (2000). Development of a measure of workplace deviance. Journal of applied psychology, 85(3), 349-360.

Berry, C. M., Ones, D. S., \& Sackett, P. R. (2007). Interpersonal deviance, organizational deviance, and their common correlates: A review and meta-analysis. Journal of applied psychology, 92(2), 410-424.

Berthelsen M, Skogstad A, Lau B, Einarsen S (2011) Do they stay or do they go? A longitudinal study of intentions to leave and exclusion from working life among targets of workplace bullying. Int J Manpower, 32(2), 178-193.

Björkqvist, K, Österman, K. ve Hjelt-Bäck, M. (1994). Aggression among university employees. Aggressive Behavior, 20, 173-184

Boddy, C. R. (2014). Corporate psychopaths, conflict, employee affective well-being and counterproductive work behaviour. Journal of Business Ethics, 121(1), 107-121.

Bolton, L. R., Becker, L. K., \& Barber, L. K. (2010). Big Five trait predictors of differential counterproductive work behavior dimensions. Personality and Individual Differences, 49(5), 537-541.

Bowling, N. A., Burns, G. N., Stewart, S. M., \& Gruys, M. L. (2011). Conscientiousness and agreeableness as moderators of the relationship between neuroticism and counterproductive work behaviors: A constructive replication. International Journal of Selection and Assessment, 19(3), 320-330.

Bruk-Lee, V. and Spector, P.E. (2006), The social stressors-counterproductive work behaviors link: are conflicts with supervisors and coworkers the same?. Journal of Occupational Health Psychology, 11(2), 145-156.

Bulutlar, F., and Unler Oz, E. (2009). The effects of ethical climates on bullying behavior in the workplace. Journal of Business Ethics, 86, 273-295.

Carnelley, K. B., \& Janoff-Bulman, R. (1992). Optimism about love relationships: General vs specific lessons from one's personal experiences. Journal of Social and Personal Relationships, 9(1), 5-20. 
Chang, K., \& Smithikrai, C. (2010). Counterproductive behaviour at work: an investigation into reduction strategies. The international Journal of Human Resource Management, 21(8), 1272-1288.

Chang, P. C. M., Su, A. T., \& Mizanur, M. M. (2018). Workplace bullying and its association with depression and self-esteem among health care workers in selected hospitals in sarawak. Occupational \& Environmental Medicine, 75(2), A340-A341.

Ciby, M., \& Raya, R. P. (2014). Exploring Victims’ Experiences of Workplace Bullying: A Grounded Theory Approach. Vikalpa, 39(2), 69-82.

Ciby, M., \& Raya, R. P. (2018). Workplace Bullying and Physical Ill-Health: Role of Negative Emotions and Perceived Organizational Support. In Indian Perspectives on Workplace Bullying (pp. 33-57). Springer, Singapore.

Colbert, A. E., Mount, M. K., Harter, J. K., Witt, L. A., \& Barrick, M. R. (2004). Interactive effects of personality and perceptions of the work situation on workplace deviance. Journal of Applied Psychology, 89(4), 599-609.

Collins, J.M. and Griffin R.W. (1998) Dysfunctional Behavior in Organizations: Violent and Deviant Behavior. In R.W. Griffin, A. O'Leary-Kelly and J.M. Collins (eds), Monographs in organizational behavior and industrial relations, Stamford, CT: JAI Press

Constantino, G. T., Domingez, J. F. M., \& Galan, J. A. G. (2006). Acoso laboral: Relaciones conla cultura organizacional y los resultados personales. Mobbing: itsrelationships with organizational culture and personel outcomes. Psicothema, 18(4), 766-771.

Cortina, L. M., Magley, V. J., Williams, J. H., \& Langhout, R. D. (2001). Incivility in the workplace: Incidence and impact. Journal of occupational health psychology, 6(1), 64-80.

Costa Jr, P. T., \& McCrae, R. R. (1992). Four ways five factors are basic. Personality and individual differences, 13(6), 653-665.

Cropanzano, R. and Mitchell, M. (2005), Social exchange theory: an interdisciplinary review. Journal of Management, 31, 874-900.

Decker, P. J. (1986). Social learning theory and leadership. Journal of Management Development, 5(3), 46-58.

Demirtas, Z. (2018). The Relationships between Organizational Values, Job Satisfaction, Organizational Silence and Affective Commitment. Online Submission, 4(11), 108125.

DeShong, H. L., Grant, D. M., \& Mullins-Sweatt, S. N. (2015). Comparing models of counterproductive workplace behaviors: The Five-Factor Model and the Dark Triad. Personality and Individual Differences, 74, 55-60.

Devonish, D. (2013). Workplace bullying, employee performance and behaviors. Employee Relations, 35(6), 630-647.

Einarsen, S., \& Mikkelsen, E.G. (2003). Individual effects of exposure to bullying at work. In S. Einarsen, H. Hoel, D. Zapf, \& C.L. Cooper (Eds.), Bullying and emotional abuse in the workplace. International perspectives in research and practice. London: Taylor $\&$ Francis.

Einarsen, S., \& Nielsen, M. B. (2015). Workplace bullying as an antecedent of mental health problems: a five-year prospective and representative study. International Archives of Occupational and Environmental Health, 88(2), 131-142.

Einarsen, S., \& Raknes, B. I. (1997). Harassment in the workplace and the victimization of men. Violence and victims, 12(3), 247-263.

Einarsen, S., Hoel, H., \& Notelaers, G. (2009). Measuring exposure to bullying and harassment at work: Validity, factor structure and psychometric properties of the Negative Acts Questionnaire-Revised. Work \& stress, 23(1), 24-44. 
Einarsen, S., Hoel, H., Zapf, D., \& Cooper, C. L. (2011). The concept of bullying and harassment at work: The European tradition. In S. Einarsen (Ed.), Bullying and harassment in the workplace: Developments in theory, research, and practice (pp. 3 40). Boca Raton, FL: Taylor and Francis.

Einarsen, S., Matthiesen, S., \& Skogstad, A. (1998). Bullying, burnout and well-being among assistant nurses. Journal of Occupational Health and Safety Australia and New Zealand, 14, 563-568.

Einarsen,S., Skogstad,A., Rørvik, E., Lande, A.B., \& Nielsen, M.B. (2018) Climate for conflict management, exposure to workplace bullying and work engagement: a moderated mediation analysis, The International Journal of Human Resource Management, 29(3), 549-570.

Elliott, R. T. (2010). Examining the relationship between personality characteristics and unethical behaviors resulting in economic crime. Ethical Human Psychology and Psychiatry, 12(3), 269-276.

Farhadi, H., Fatimah, O., Nasir, R., \& Shahrazad, W. W. (2012). Agreeableness and conscientiousness as antecedents of deviant behavior in workplace. Asian Social Science, 8(9), 2-7.

Farr-Wharton, B., Shacklock, K., Brunetto, Y., Teo, S. T., \& Farr-Wharton, R. (2017). Workplace bullying, workplace relationships and job outcomes for police officers in Australia. Public Money \& Management, 37(5), 325-332.

Fox, S., \& Stallworth, L. E. (2005). Racial/ethnic bullying: Exploring links between bullying and racism in the US workplace. Journal of Vocational Behavior, 66, 438-456.

Fox, S., Spector, P. E., \& Miles, D. (2001). Counterproductive work behavior (CWB) in response to job stressors and organizational justice: Some mediator and moderator tests for autonomy and emotions. Journal of vocational behavior, 59(3), 291-309.

Francioli, L., Høgh, A., Conway, P. M., Costa, G., Karasek, R., \& Hansen, Å. M. (2016). Do personal dispositions affect the relationship between psychosocial working conditions and workplace bullying? Ethics \& Behavior, 26(6), 451-469.

Glambek, M., Nielsen, M. B., Gjerstad, J., \& Einarsen, S. (2018). Gender differences in the relationship between workplace bullying and subjective back and neck pain: A twowave study in a Norwegian probability sample. Journal of psychosomatic research, $106,73-75$.

Glambek, M., Skogstad, A., \& Einarsen, S. (2018). Workplace bullying, the development of job insecurity and the role of laissez-faire leadership: A two-wave moderated mediation study. Work \& Stress, 32(3), 1-16.

Glasø, L., Matthiesen, S. B., Nielsen, M. B., \& Einarsen, S. (2007). Do targets of bullying portray a general victim personality profile? Scandinavian Journal of Psychology, 48, 313-319.

Greenberg, J. (1997). The STEAL motive: Managing the social determinants of employee theft. In R. A. Giacalone \& J. Greenberg (Eds.), Antisocial behavior in organizations: Sage Publications, Inc.

Gruys, M. L., \& Sackett, P. R. (2003). Investigating the dimensionality of counterproductive work behavior. International journal of selection and assessment, 11(1), 30-42.

Gültaç, A. S. and Erigüç, G. (2019). Geçmişten Günümüze Örgütlerde Üretkenlik Karşıtı İş Davranışları: Kavramsal Bir Bakış Açısı. Pamukkale Üniversitesi Sosyal Bilimler Enstitüsü Dergisi, 36, 51-68.

Gürbüz, S. (2019). Aracı, Düzenleyici ve Durumsal Etki Analizleri, Ankara: Seçkin Kitabevi.

Hafidz, S. W. M. (2012). Individual differences as antecedents of counterproductive work behaviour. Asian Social Science, 8(13), 220-226. 
Harlos K., Knoll M. (2018) Employee Silence and Workplace Bullying. In: D'Cruz P. et al. (eds) Pathways of Job-related Negative Behaviour. Handbooks of Workplace Bullying, Emotional Abuse and Harassment, Singapore: Springer.

Hastings, S. E., \& O’Neill, T. A. (2009). Predicting workplace deviance using broad versus narrow personality variables. Personality and Individual Differences, 47(4), 289-293.

Hauge, L. J., Skogstad, A., \& Einarsen, S. (2009). Individual and situational predictors of workplace bullying: Why do perpetrators engage in the bullying of others? Work \& Stress, 23(4), 349-358.

Hauge, L., Skogstad, A. and Einarsen, S. (2010). The relative impact of workplace bullying as a social stressor at work. Scandinavian Journal of Psychology, 51(9), 426-433.

Hayes, A. F. (2018). Partial, conditional, and moderated moderated mediation: Quantification, inference, and interpretation. Communication Monographs, 85(1), 4-40.

Herschcovis, M. S., \& Barling, J. (2010). Towards a multi-foci approach to workplace aggression: A meta-analytic review of outcomes from different perpetrators. Journal of Organizational Behavior, 31(1), 24-44.

Heyde, A. V. D., Miebach, J., \& Kluge, A. (2014). Counterproductive work behaviour in a simulated production context: An exploratory study with personality traits as predictors of safety-related rule violations. J Ergonomics, 4(130), 1-9.

Hitlan, R. T., \& Noel, J. (2009). The influence of workplace exclusion and personality on counterproductive work behaviours: An interactionist perspective. European Journal of Work and Organizational Psychology, 18(4), 477-502.

Hitlan, R. T., Cliffton, R. J., \& DeSoto, M. C. (2006). Perceived exclusion in the workplace: The moderating effects of gender on work-related attitudes and psychological health. North American Journal of Psychology, 8, 217-236.

Hoel, H., Sheehan, M., Cooper, C. L., \& Einarsen, S. (2011). Organisational effects of workplace bullying. In S. Einarsen, H. Hoel, D. Zapf, \& C. L. Cooper (Eds.), Bullying and harassment in the workplace. CRC Press.

Hogan, J., \& Hogan, R. (1989). How to measure employee reliability. Journal of Applied psychology, 74(2), 273-279.

Hooper, D. and Martin, R. (2008). Beyond personal leader-member exchange (LMX) quality. Leadership Quarterly, 19, 20-30.

Hsieh, Y. H., Wang, H. H., \& Ma, S. C. (2019). The mediating role of self-efficacy in the relationship between workplace bullying, mental health and an intention to leave among nurses in Taiwan. International journal of occupational medicine and environmental health, 32(2), 245-254.

Instone, K. (2012). Counterproductive Work Behavior. White paper. Auckland, New Zealand: University of Auckland.

Jensen, J. M., Patel, P. C., \& Raver, J. L. (2014). Is it better to be average? High and low performance as predictors of employee victimization. Journal of Applied Psychology, 99, 296-309.

Jex, S. M., \& Beehr, T. A. (1991). Emerging theoretical and methodological issues in the study of work-related stress. Research in personnel and human resources management, 9(31), 1-365.

Judge, T. A., \& Ilies, R. (2002). Relationship of personality to performance motivation: A meta-analytic review. Journal of applied psychology, 87(4), 797.

Kaya, Ş.D., Tekpınar, L., and Tekin, G. (2019). İş Yeri Zorbalığı ve Sinizm: Sağlık Kurumlarında Çalışan Güvenliği Bağlamında Değerlendirilmesi, Selçuk Üniversitesi, Sosyal Bilimler Enstitüsü Dergisi, 42, 1-22.

Keashly, L. (1998). Emotional abuse in the workplace: Conceptual and empirical issues. Journal of Emotional Abuse, 1, 85-117. 
Kelloway, E. K., Francis, L., Prosser, M., \& Cameron, J. E. (2010). Counterproductive work behavior as protest. Human Resource Management Review, 20(1), 18-25.

Kim, E., \& Glomb, T. M. (2014). Victimization of high performers: The roles of envy and work group identification. Journal of Applied Psychology, 99, 619-634.

Kish-Gephart, J. J., Harrison, D. A., \& Treviño, L. K. (2010). Bad apples, bad cases, and bad barrels: meta-analytic evidence about sources of unethical decisions at work. Journal of applied psychology, 95(1), 1-31.

Koç, F.P. and Bayraktar., O. (2019). Üretkenlik Karşıtı İş Davranışları Üzerinde Kişilik Özelliklerinin Etkisi, İstanbul Ticaret Üniversitesi Sosyal Bilimler Dergisi, 18, 19-39.

Kozako, I. N. A. M. F., Safin, S. Z., \& Rahim, A. R. A. (2013). The relationship of big five personality traits on counterproductive work behaviour among hotel employees: An exploratory study. Procedia Economics and Finance, 7, 181-187.

Lallukka, T., Rahkonen, O., \& Lahelma, E. (2011). Workplace bullying and subsequent sleep problems - the Helsinki Health Study. Scandinavian Journal of Work, Environment \& Health,37(3), 204-212.

Lever, I., Dyball, D., Greenberg, N., \& Stevelink, S. A. (2019). Health consequences of bullying in the healthcare workplace: A systematic review. Journal of advanced nursing, 3195-3209.

Leymann, H. (1996). The Content and Development of Mobbing at Work. European Journal of Work and Organizational Psyhology, 5(2), 165-184.

Lind, K., Glasø, L., Pallesen, S., \& Einarsen, S. (2009). Personality profiles among targets and nontargets of workplace bullying. European Psychologist, 14(3), 231-237.

Livne, Y., \& Goussinsky, R. (2018). Workplace bullying and burnout among healthcare employees: The moderating effect of control-related resources. Nursing \& health sciences, 20(1), 89-98.

Lutgen-Sandvik, P., Tracy, S. J., \& Alberts, J. K. (2007). Burned by bullying in the American workplace: Prevalence, perception, degree, and impact. Journal of Management Studies, 44, 837-862.

Martinko, M. J., Gundlach, M. J., \& Douglas, S. C. (2002). Toward an integrative theory of counterproductive workplace behavior: A causal reasoning perspective. International Journal of Selection and Assessment, 10(1-2), 36-50.

Matthiesen, S. B. ve Einarsen, S. (2004). Psychiatric distress and symptoms of PTSD among victims of bullying at work. British Journal of Guidance \& Counselling, 32, 335-356.

McCrae, R. R., \& Costa, P. T. (1991). Adding Liebe und Arbeit: The full 5-factor model and wellbeing. Personality and Social Psychology Bulletin, 17, 227-232.

McCrae, R. R., \& John, O. P. (1992). An introduction to the 5-factor model and its applications. Journal of Personality, 60, 175-215.

Mikkelsen, E. G., \& Einarsen, S. (2002). Relationships between exposure to bullying at work and psychological and psychosomatic health complaints: The role of state negative affectivity and generalized self-efficacy. Scandinavian journal of psychology, 43(5), $397-405$.

Miller, P., Brook, L., Stomski, N. J., Ditchburn, G., \& Morrison, P. (2019). Depression, suicide risk, and workplace bullying: a comparative study of fly-in, fly-out and residential resource workers in Australia. Australian health review, 44(2), 248-253.

Nasir, M., \& Bashir, A. (2012). Examining workplace deviance in public sector organizations of Pakistan. International Journal of Social Economics, 39(4), 240-253.

Nielsen, M. B., \& Knardahl, S. (2015). Is workplace bullying related to the personality traits of victims? A two-year prospective study. Work \& Stress, 29(2), 128-149. 
Nielsen, M. B., Matthiesen, S. B., \& Einarsen, S. (2008). Sense of coherence as a protective mechanism among targets of workplace bullying. Journal of Occupational Health Psychology, 13, 128-136.

O’Moore,M., Seigne,E., McGuire,L., \& Smith,M. (1998) Victims of workplace bullying in Ireland, The Irish Journal of Psychology, 19(2-3), 345-357.

Öksüzoğlu, T. and Şeşen, H. (2018). Kuzey Kıbrıs Türk Cumhuriyeti Kamu İşyerlerinde Mobbing Olgusu: Sendikaların Rolü Üzerine Nitel Bir Araştırma. Amme İdaresi Dergisi, 51(1), 133-166.

Ones, D. S., \& Viswesvaran, CC. (1996). A theory of conscientiousness at work. Paper presented at the 11th annual conference of the Society for Industrial and Organisational Psychology, San Diego: CA.

Özkalp, E. and Kırel, Ç.(2016). Örgütsel Davranış, Bursa: Ekin Basın Yayın Dağıtım.

Parzefall, M. R., \& Salin, D. M. (2010). Perceptions of and reactions to workplace bullying: A social exchange perspective. Human Relations, 63, 761-780.

Penney, L. M., Hunter, E. M., \& Perry, S. J. (2011). Personality and counterproductive work behaviour: Using conservation of resources theory to narrow the profile of deviant employees. Journal of Occupational and Organizational Psychology, 84(1), 58-77.

Persson, R., Høgh, A., Grynderup, M. B., Willert, M. V., Gullander, M., Hansen, Å. M., ... \& Kaerlev, L. (2016). Relationship between changes in workplace bullying status and the reporting of personality characteristics. Journal of occupational and environmental medicine, 58(9), 902-910.

Pervin L.(1993). Personality. Theory and Research. New York: John Wiley \& Sons Inc.

Purpora, C., Cooper, A., Sharifi, C., \& Lieggi, M. (2019). Workplace bullying and risk of burnout in nurses: a systematic review protocol. JBI database of systematic reviews and implementation reports, 17(12), 2532-2540.

Quine, L. (2001). Workplace bullying in nurses. Journal of health psychology, 6(1), 73-84.

Robinson, S. L., \& Bennett, R. J. (1995). A typology of deviant workplace behaviors: A multidimensional scaling study. Academy of management journal, 38(2), 555-572.

Rodriguez-Munoz A, Baillien E, De Witte H, Moreno-Jimenez B, Pastor JC (2009) Crosslagged relationships between workplace bullying, job satisfaction and engagement: two longitudinal studies. Work Stress 23(3), 225-243.

Rodríguez-Muñoz, A., Moreno-Jiménez,B., \& Sanz-Vergel,A.S. (2015). Reciprocal relations between workplace bullying, anxiety, and vigor: a two-wave longitudinal study. Anxiety, Stress \& Coping, 28(5), 514-530.

Salin, D. (2015). Risk factors of workplace bullying for men and women: The role of the psychosocial and physical work environment. Scandinavian journal of psychology, 56(1), 69-77.

Salin, D., \& Hoel, H. (2011). Organizational causes of workplace bullying. In S. Einarsen, H. Hoel, D. Zapf, \& C. L. Cooper (Eds.), Bullying and harassment in the workplace: Developments in theory, research, and practice (2nd ed., pp. 227-243). London, UK: Taylor \& Francis

Samnani, A. K., \& Singh, P. (2014). Performance-enhancing compensation practices and employee productivity: The role of workplace bullying. Human Resource Management Review, 24(1), 5-16.

Scherer, K. T., Baysinger, M., Zolynsky, D., \& LeBreton, J. M. (2013). Predicting counterproductive work behaviors with sub-clinical psychopathy: Beyond the Five Factor Model of personality. Personality and Individual Differences, 55(3), 300-305.

Semmer, N. (2003). Individual differences, work stress and health. In S. Mj, J. A. M. Winnubst, \& C. L. Cooper (Eds.), Handbook of work and health psychology (pp. 83120). New York, NY: Wiley. 
Somer, O. (1998). The structure of adjectives defining personality traits in Turkish and the five-factor model. Turk Psikoloji Dergisi, 13(42), 17-32.

Spector, P. E., \& Fox, S. (2005). The Stressor-Emotion Model of Counterproductive Work Behavior. In. Fox, S., \& Spector, P. E. (Eds.). Counterproductive work behavior: Investigations of actors and targets. Washington, DC: American Psychological Association.

Spector, P. E., \& Jex, S. M. (1998). Development of four self-report measures of job stressors and strain: interpersonal conflict at work scale, organizational constraints scale, quantitative workload inventory, and physical symptoms inventory. Journal of occupational health psychology, 3(4), 356-367.

Spector, P. E., Fox, S., Penney, L. M., Bruursema, K., Goh, A., \& Kessler, S. (2006). The dimensionality of counterproductivity: Are all counterproductive behaviors created equal?. Journal of vocational behavior, 68(3), 446-460.

Trevino, L. K., \& Youngblood, S. A. (1990). Bad apples in bad barrels: A causal analysis of ethical decision-making behavior. Journal of Applied psychology, 75(4), 378-385.

Witt, L. A., Burke, L. A., Barrick, M. R., \& Mount, M. K. (2002). The interactive effects of conscientiousness and agreeableness on job performance. Journal of Applied Psychology, 87(1), 164-169. 